\title{
https://helda.helsinki.fi
}

\section{Intohimon fonesteemi ja kiireen etymologia}

\author{
Junttila, Santeri
}

Suomalais-Ugrilainen Seura

2020

Junttila , S 2020 , Intohimon fonesteemi ja kiireen etymologia . julkaisussa S Holopainen , J pÿkuokkala , J Saarikivi \& S Virtanen (toim), $\angle 0 A$ AK<KÈ =M:25 2>@BC@ MB?>AB A0<K= pÿ?0BC < : Scripta miscellanea in honorem Ulla-Maija Forsberg . Suomalais-Ugrilaisen Seuran pÿToimituksia , Vuosikerta. 275 , Suomalais-Ugrilainen Seura, Helsinki, Sivut 158170 . https://doi.org/10.33341/su

http://hdl.handle.net/10138/339671

https://doi.org/10.33341/sus. 11.11

unspecified

publishedVersion

Downloaded from Helda, University of Helsinki institutional repository.

This is an electronic reprint of the original article.

This reprint may differ from the original in pagination and typographic detail.

Please cite the original version. 


\section{Intohimon fonesteemi ja kiireen etymologia}

Ulla-Maija Forsbergin kiistämättömiin ansioihin etymologina kuuluu fonesteemin käsitteen määrittely ja käyttöönotto uralistiikan kontekstissa. Monografiassaan Fonesteemit ja sananmuodostus Forsberg kuvaa fonesteemin ekspressiivisen sananmuodostuksen yksikkönä, joka edustaa konventionaalista äännesymboliikkaa ja sisältää usein myös synesteettisen äännesymboliikan aineksia. Työstä ilmenee myös, että fonesteemien lähtökohtana on usein imitatiivinen äännesymboliikka. Yksittäinen fonesteemi voi olla hyvinkin vanha, jopa kantauralilainen, muttei ole välttämättä koskaan esiintynyt kielessä vapaana morfeemina ja sen myötä perinteisenä kantasanana. Uralilaiset fonesteemit Forsberg esittää muodossa \#CVCi-; jälkivokaali $i$ on ”suomalais-ugrilaisista sanavartalon loppuvokaaleista kevein" (Kulonen 2010: 94-97).

"Etymologisessa tutkimuksessa on tähän saakka virheellisesti yhdistetty keskenään kaukaisista sukukielistä nuoria deskriptiivisanoja, kun pitäisi hakea niiden taustalta äänteellisiä konventioita, joihin liittyy kuvaileva ja sellaisena ekspressiivinen semanttinen mielikuva. Äänteellisten konventioiden pohjaltahan kielissä luodaan uutta deskriptiivisanastoa, joka enimmäkseen, kuten itämerensuomessa, on varsin nuorta.” (Mts. 16). Tähän haluaisin lisätä, että uutta deskriptiivisanastoa saadaan myös kielikontakteissa, kun olemassa olevat fonesteemit vetävät puoleensa - toisin sanoen houkuttelevat lainaamaan - sanoja, joihin niitten konventionaalinen äännesymboliikka on laajennettavissa.

Hans Sperberin jo sata vuotta sitten esittämien, usein siteerattujen ajatusten mukaan ekspressiivinen sananmuodostus liittyy äänteellisen varioinnin keinona käsitteitten tunnelataukseen eli affektiin, sillä affektiiviset käsitepiirit muodostavat attraktiokeskuksia, jotka vetävät puoleensa muitten käsitepiirien sanoja ja ajavat sanastoaan uusiutumaan ja varioimaan niin voimallisesti, etteivät "normaalin" sananjohdon keinot riitä (Sperber 1923: 45-49; vrt. Hakulinen 1933). Samat attraktiokeskukset 
vetävät kuitenkin puoleensa myös lainasanoja, ja tällaiset lainat ovat alttiita motivoitumaan uusiksi ja ekspressiivistymään (vrt. Jarva 2003: 96-IO2). Ehdotankin, että juuri kielen konventionaalinen äännesymboliikka, jota voidaan kuvata fonesteemien avulla, ohjaa tällöin lainautumista pyydystämällä tarjolla olevista lähtömuodoista kielessä valmiina oleviin muotteihin sopivimmat.

Tutkailen tässä artikkelissa Forsbergin (mts. 2010: I08) itämerensuomeen ja saameen rekonstruoimaa fonesteemia \#kiri-, johon "yhdistyy sekä kova pistävä ääni että hapan tai karvas makuaistimus ja tietenkin myös silmään pistävä (kirkas) valo”. Vanhin fonesteemin yhteyteen kuuluva sana on kireä, jolla on vastineita paitsi itämerensuomessa - ka. kirie 'rutikuiva; äkäinen', kiristeä 'kylmetä', kiristyö 'kuivettua', va. tširissï̈̈ 'kuivettua, kutistua', vi. kiristada' 'puristaa, pusertaa' - myös saamessa: saaP garra : garas 'kova; väkevä; kiivas, ankara'. Selvimmin onomatopoieettisia fonesteemin pesyeeseen kuuluvista sanoista ovat -k-tilkkeellä (vrt. s. 239) muodostetut kirkua, kirkkua ja kirskua, joilla on laaja itämerensuomalainen levikki. Samat ainekset, \#kirifonesteemin ja -k-tilkkeen Forsberg jäljittää myös adjektiiviin kirkas (sm. ka. va. vi.).

Tässä en käsittele Forsbergin \#kiri-fonesteemin yhteyteen liittämiä - $p$ - ja - $m$-tilkkeillä laajennettuja sanoja, vaan rajoitan aiheeni tilkkeettömiin ja - $k$-tilkkeellisiin sanoihin. Edellisiin kuuluu selvästi myös viron tilkekonsonantiton kireda 'kiekua' ja ehkä vielä suomen kire'riite, huurre, ohut (jä)kuori tms.; pakkaskeli; pieni, kuivettunut', jos sen lähtömotivaationa on ollut 'kuivuus' tai 'ankara kylmyys'.

\#kiri-fonesteemin merkityspiirteitä on myös kahdella äänteellisesti läheisellä itämerensuomalaisella sanueella, joihin kuitenkin liittyy myös 'himon, kiiman' ja 'intohimon' merkityksiä: *kiiras $\sim^{*}$ kiiri ja ${ }^{*}$ kirki.

Etelävirossa Võrtsjärven ympäristön pitäjistä on merkitty kiirras merkityksessä 'raisu, kevytmielinen; himokas, kiimainen', idempää Räpinästä ja pohjoisviron itämurteen puolelta Kodaverestä samanmerkityksinen kiirakas. Sen vastineena on yleensä (mm. SKES, SSA) pidetty suomen adjektiivia kiiras, jolle Suomen murteiden sanakirja mainitsee merkitykset 'peräänantamaton, tiukka (Mikkeli, Hirvensalmi); kitsas, nuuka (Vuoksenranta); kova, tiukka (paikka)'. Vanhassa kirjasuomessa kiiras esiintyy Kollaniuksen lainsuomennoksessa vuodelta 1648 yhteydessä kirasja äkillinen tuittu (vrt. SSA).

Suomen kiiras tulee siis paljon lähemmäs 'kireän' semantiikkaa kuin siihen yhdistetty eteläviron sanue. Fonesteemin \#kiri- merkityskenttään sopivat myös lyhyt-i:llinen kiras, joka Pohjois-Satakunnasta ja Etelä-Pohjanmaalta on kirjattu sanonnassa ottaa kiraille'suututtaa', sekä pohjoismurteista ja Kainuusta tavattu kiiri (myös kiire) '(paha) mieliala, tuuli; into, vimma; tuuri; vuoro'. 'Kirkkauteen' taas liittyvät mm. kiirastuli, alun perin 'puhdistustuli', SMS:n mainitsema kiirasilmä (Sonkajärvi, Kuusamo) 'kirkassilmä' ja ka. kiirakka 'kirkas', Lönnrot mainitsee sanalle kiira sekä merkityksen 'bråd, häftig' että 'ren o. blank'. Tähän on lisättävä, että satakuntalais- ja hämäläismurteissa kireä merkitsee myös 'hellittämätöntä, lujaa, vaativaa' (SMS).

Kirki (: kirje-) 'lemmenpalo, kiima, himo; pistävä ihmisen haju' (SMS) on suomessa vain itämurteista harvakseltaan tavattu ja säilynyt lähinnä kansanrunoissa, mutta itämerensuomessa sillä on laaja levikki. Eteläkarjalan ja livvin vastineella kirgi on sama 
'himokkuuden' merkitys (KKS). Myös viron kirg on nykykielessä 'intohimo, kiihko', mutta Saarenmaan, Länsi-Viron ja Kodaveren murteissa on sillä konkreettinen merkitys 'kipinä' (EMS).

Tästä sanapesyeestä on tehnyt mainion selvityksen jo Lauri Hakulinen (1933) lähtökohtanaan Lönnrotin ja Krohnin mainitsema suomalais-karjalainen "naimakiihkon haltia kirki'. Hakulinen hahmotteli merkityksen 'kiihko' kehittyneen merkityksestä 'kipinä', vaikkei edes vielä tiennyt eteläviron ja liivin vastineista, jotka vahvistavat kehityssuunnan. Etelävirossa (kirǵ) ja liivissä (kireg, kirüg) merkitys 'kipinä' on yksinomainen lukuun ottamatta Urvastesta muistiin merkittyä merkitystä 'liekki'. Tämä sanue on siis kahdesta päästänsä yhteydessä \#kiri-fonesteemiin: ensinnäkin 'kirkkauden' ja toissijaisesti myös 'pistävän hajun' merkityksen kautta.

Myös muodollisin kriteerein sekä kiiras että kirki sopisivat fonesteemin \#kiriyhteyteen, sillä ekspressiivisessä sanastossa vartalon laajentamiseen on kaksi keinoa, tilkkeen käyttäminen ja vokaalin pidentäminen (Kulonen 20IO: 252). Sitä paitsi - $k$ on teoksen (s. 239) aineistossa tilkekonsonanteista yleisin. Affektia on merkityksessä mukana enemmän kuin "hitunen" (vrt. s. 94), joten kumpaakin sanuetta voi pitää ekspressiivisenä.

Alkuperänselityksenä tässä tulkinnassa on kuitenkin ainakin kolme ongelmaa. Ensinnäkin vartalon laajentamiseen tulisi liittyä jonkinlaista synesteettistä äännesymboliikkaa kuten pitkäkestoisuutta tai suhteellista hitautta (vrt. s. 95, 235, 24I), johon 'himokkuus' sopii huonosti, 'kipinä' ja 'äkillisyys' vielä heikommin. Toiseksi kiiras on selitetty kahdesta eri germaanisesta lähteestä, joista toinen liittyy 'puhtauteen' ja 'kirkkauteen', toinen 'intohimoon'. Kolmanneksi kirjen konkreettinen lähtömerkitys 'kipinä' tulisi johtaa abstraktista 'kirkkaudesta'.'

\section{Nuoret kiiraat}

Ensimmäisen lainaetymologian suomen kiiras-sanalle on esittänyt Streng (1915: 63) muinaisskandinaavin adjektiivista skirr'puhdas, kirkas, kiiltävä’. LägLoS (1996, s.v. kiiras ${ }^{2}$ ) pitää Strengin etymologiaa mahdollisena vain yhdyssanojen kiirastorstai ja kiirastuli alkuosille ja huomauttaa, ettei muinaisruotsista ole tavattu odotuksenmukaisia yhdysmuotoja * skirsla-porsdagher 'kiirastorstai' tai *skirsl-eldher 'kiirastuli', vaan ainoastaan skarseldher 'kiirastuli', joka vokaalinsa puoleksi ei sovi lainanlähteeksi. Erikseen lainautuneena LägLoS pitää Lönnrotin mainitsemaa adjektiivia kiira 'puhdas, kirkas'. Se on kuitenkin voinut hyvin lainautua muinaisskandinaavista itämerensuomen pohjoismurteisiin jo ennen kiirastorstaita ja kiirastulta, onhan se osana paitsi yllä mainituissa sanoissa kiirasilmä 'kirkassilmä' ja ka. kiirakka 'kirkas' (vrt. kiilakka id.), myös SSA:n mainitsemissa rasvan käsittelyyn liittyvissä verbeissä kiirata 'puhdistaa' ja

I. Artikkelini vertaisarvioijaa kiitän vielä neljännen ongelmakohdan osoittamisesta: hänen mukaansa Forsbergin aineistossa ole yhtään sanaa, jossa ensi tavun - $i$ - olisi sekundääristi pidennyt $r$ :n edellä. 
kiirastua, kiiraintua 'puhdistua'. Tämä kiira on voinut kansanetymologisesti yhdistyä muinaisruotsin sker-määriteosaan sanoissa sker-s-eldher ja ${ }^{*}$ skär-s-porsdagher, jolloin kiirastulen ja kiirastorstain -s- edustaisi lähinnä muinaisruotsin genetiivin päätettä.

Uudemman kiiras-lainaselityksen on esittänyt Koivulehto (1974: I23): sm. kiiras 'äkillinen, raju, kova', vs. kiiras 'levoton, epävakainen, liikkuva, kiireinen, tulinen, himokas, kiimainen' $\leftarrow$ kge. ' gi-ra-z, vrt. sa. Geier 'korppikotka'. Se perustunee Klugen ja Mitzkan (1967 s.v. Geier) tarjoamalle oletukselle, että länsigermaaninen korppikotkan nimitys * gir-(a)n on adjektiivin mas. gir kysa. gire 'ahne' substantiivistuma. Tämän adjektiivin johdoskorrelaatteja on nykysaksan Gier 'halu, himo, intohimo', josta puolestaan on johdettu adjektiivi gierig 'halukas, ahne, himokas, ahmatti'. Ongelmana on kuitenkin, että muinais(ala)saksin ja keskiyläsaksan sanakirjoista löytyy tästä adjektiivista vain lyhytvokaalisia muotoja, jotka Klugen uudemmat painokset mainitsevat pitkävokaalisten sijaan. Jo LägLoS (1996, s.v. kiiras ${ }^{I}$ ) kritisoi Koivulehdon etymologiaa tältä pohjalta. Kantagermaanin tuoreemmat etymologiset sanakirjat (HGE 2003, EDPG 2013) eivät nekään oleta pitkävokaalista adjektiivia * giraz.

Toinen muinaisgermaanisen etymologian kannalta epäilyttävä seikka on eteläviron ja suomen kiiras-adjektiivien merkitysero. Suomen sanalta ei löydy merkityksiä 'kevytmielinen' eikä 'himokas, kiimainen', jotka eteläviron adjektiivilla ovat EMS:n mukaan yksinomaiset: kiiras, kiirakas on siis synonyymi koko Viron alueella tunnetulle adjektiiville tiiras 'kiimainen'. Kodaveressä ja Póltsamaalla kiirakas merkitsee myös 'nopeata, sukkelaa' eli samaa kuin vi. kiire, mutta etelävirossa kiire-sanalla ei ole vastinetta, joten enintään Kodaveren ja Pôltsamaan kiirakas voi olla sen johdos. Niinpä eteläviron kiiras-adjektiivin taustalla lienee saksan gierig merkityksessä 'halukas, himokas', mutta sen mukautumista -as-päätteiseen tyyppiin voitaneen kiittää synonyymiä tiiras. Sen ei siis tarvitse olla suomen kiiras-sanan vastine.

Suomenkaan kiiras ei ole kovin laajalevikkinen. Yleisimmin tunnetussa merkityksessänsä 'kova, tiukka (paikka)' se on selitettävissä sanan kiirastuli lyhentymänä. Erilähtöiselle adjektiiville kiiras 'peräänantamaton, tiukka; kitsas, nuuka' jä siis vain eteläsavolais-eteläkarjalainen murrelevikki. Aluetta kuitenkin laajentaa jonkin verran karkkulaissyntyisen Kollaniuksen käyttämä (mahdollisesti lyhytvokaalinen!) kiras sekä hieman lännempää tavattu verbijohdos kiirastaa 'vaatia itsepintaisesti, kovistaa'. Ruotsin girig-adjektiivilla on kirjakielisten merkitysten 'ahne, saita, kitsa, itara; himokas' lisäksi yleinen murremerkitys 'työteliäs, ahkera; sitkeä, sinnikäs', joten semanttisesti se periaatteessa riittää suomen sanan lainanlähteeksi, mutta jonkinasteinen merkityssiirtymä kohti \#kiri-fonesteemia on myös havaittavissa ('kireä' 'tiukka, peräänantamaton'). Sanan -as-päätteen selitykseksi LägLoS ehdottaa vaikutusta äänteellisesti ja merkitykseltään läheisestä adjektiivista kiivas. Niinpä sekä suomen että eteläviron kiiras-sanat voidaan selittää suhteellisen nuoriksi lainoiksi.

LägLoS mainitsee kiiraan ${ }^{I}$ yhteydessä substantiivin kiiri ( kiire) '(paha) mieliala; into, vimma; tuuri; vuoro' (kiirillään, kiirissä 'pahalla tuulella'), mutta sitä tavataan vain Himanka-Nurmes-linjan pohjoispuolelta. Kyseessä on todennäköisesti erillinen laina, ehkäpä girig-adjektiiviin liittyvästä substantiivikorrelaatista 
(takaperojohdoksesta?) gir 'himo, halu', joka on säilynyt kirjallisiin lähteisiin asti vain norjan murteissa, mutta on voinut aiemmin kuulua ruotsinkin (pohjoisiin) murteisiin. Lainaselitys edellyttää, että kiirinkin lähtömerkityksenä voidaan pitää '(into)himoa, halua'. Muutamassa SMS:n esimerkkilauseessa kiiri onkin hyvin korvattavissa sanalla intohimo tai halu: se meni Pekalta se kiiri obi (Himanka); kun tuli semmonen kiiri, että ostetaan siammarijav varsia Ouluun (Hailuoto); välistä on ettei kalà otà milhä̈̈n (onkeen) ku se ei olè hänèn kiirinsä (Kolari); tytöstä, joka "vahtaa poikia”: kiirilhään (Simo). Toisaalta merkityksen '(paha) mieliala' lähtökohtana saattaa olla myös ru. gir '(laivan) käännös, kurssimuutos'.

\section{Vanha kirki}

Kirki-sanan osoittavat varsin vanhaksi sen vastineet pohjoissaamessa, garga'suihku, ruiskaus' ja gargit'säkenöidä, kipunoida, tupruta'. SSA merkitsee saamen vastineet kysymysmerkillä, mutta syynä on luultavasti semanttinen ero, joka vaikuttaa suurelta, kun lähtökohtana on suomesta tavattu merkitys 'kiima, himo'. Ongelma poistuu, kun Hakulisen (1933: 163) tavoin tulkitsemme etelämpänä säilyneen 'kipinä'-merkityksen alkuperäiseksi: "Mitä ensinnäkin tulee merkityksenkehitykseen 'tuli' > 'polte' > 'intohimo', huomautettakoon, että 'kovaa halua' usein ilmaistaan kuvaannollisesti 'tulen, poltteen' tms. nimityksellä'. Hakulinen havainnollistaa 'poltteen' ja 'himon' yhteyttä vaikuttavalla valikoimalla sananlaskuja ja murre-esimerkkejä, josta edustavimpina mainittakoon "Kirki piiassa palaapi, kirki piian kintahassa", "Hiili on nuoren hiassa, tuli neidon pohkeassa, kekäleitä kantapäässä", ”Tulisoitto morsiamen hameen alla” ja "mieli kytevi kylän pojille". Lopulta myös saksan Brunst 'kiima' on johdos verbistä brennen 'palaa'.

Toisena semanttisena paralleelina voisi mainita myös suomen sanan abku, jonka alkuperäinen ja lainaoriginaalin merkitys on 'tuhka', mutta joka suomen kaakkoismurteissa tarkoittaa myös 'intoa, kiihkoa, kovaa halua' (SSA). 'Kipinä' on myös avain koko sanueen alkuperään, joka löytyy balttilaiselta taholta.

Latvia-suomi-latvia-sanakirja kääntää kipinän sanoilla dzirksts, dzirkstele. Fraenkel (LEW) mainitsee sanan dzirkstele'Funke' hakusanan lt. garas '(Wasser)dampf, leidenschaftlicher Wunsch, heftige Begierde, eifriges Streben, Eifer' alla. Sinne Fraenkel on koonnut laajan joukon balttilaisia ja slaavilaisia johdoksia indoeurooppalaisesta, hyvin laajalevikkisestä juuresta ${ }^{*} g^{w h} o r$-, jonka lähtömerkitykset liittyvät kuumaan ja palamiseen. Karulis (LEV s.v. dzirksts) täsmentää, että kysymys on katoasteisesta $k$-johdoksesta ${ }^{*} g^{w h} r-k$-, jolla ei ole vastineita latvian ulkopuolella. Latviassa siihen liitty-

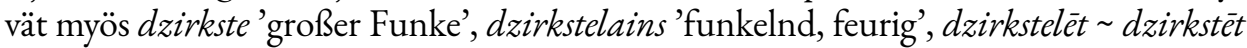
'Funken sprühen, funkeln', dzirkstība 'Feurigsein' ja dzirkstït 'fimmeln' (ME). Sanan -st-aines on luultavasti < itäbaltin ${ }^{*}-s t$ - eikä siksi näy itämerensuomen lainavartalossa, jonka lähtömuodoksi voi kantabalttiin rekonstruoida kannan * girk-(> lv. dzirk-).

2. Tästä huomiosta kiitän artikkelini vertaisarvioijaa. 
Koska dzirkst-sanueen levikki rajoittuu latviaan, on syytä kysyä, eikö lainaussuunta voisi olla vastakkainen. Vastaus on kuitenkin kielteinen, sillä latviassa ei ole varmoja itämerensuomalaisia lainoja ajalta ennen äänteenmuutosta $k>c, g>d z$ : vain cimds 'kinnas' voisi sopia sellaiseksi, mutta senkin yleensä katsotaan lainautuneen vastakkaiseen suuntaan.

Fraenkelin ja Karuliksen selitys ei kuitenkaan ole aivan ongelmaton. Matasović (2008: III) nimittäin selittää, että indoeurooppalaisen vokaalisen rọ :n säännöllisenä jatkajana tulisi velaariklusiilin jäljessä olla kantabalt(oslaav)in -ur- eikä -ir-. Analogisia poikkeuksia sääntöön on lukuisia, mutta ${ }^{*} g^{w h} o r$-juuren katoasteen varmoihin edustuksiin palautuu -ur-: ven. греть, греватtъ 'wärmen', mksl. гърмв 'Becken, Kessel' (LEW s.v. garas) $<$ ksl. * gur-.

Mahdollisesti vartalon kba. * ${ }^{*}$ irk- > lv. dzirk- äänneasuun liittyvät liettuan verbi žirti (prees. žiru t. žirstu) 'streuend auseinanderfahren; funkeln' ja sen johdos žirgsnis (= pirkšnis, žiežirga) 'glühende Kohle, sprühende Glut, Funke' (Kurschat LDW). Derksen (EDBIL) liittää ne indoeurooppalaiseen juureen ${ }^{*} \dot{g}^{(h)} e r(H)$-, josta on johdettu myös lt. žerèti 'im Glänze strahlen, funkeln, glitzern, glänzen' (josta $\rightarrow$ vi. ere, vs. herre 'kirkas, halakka; kuuma, polttava', vrt. Junttila 20I5: 220). Tämä juuri ei ole laajalti tunnettu kuten ${ }^{*} g^{w h}$ or-, vaan sen levikki rajoittuu baltoslaaviin. Indoeuropeistiikan asiantuntijain ratkaistavaksi jää kysymys, voisiko se ollakin vain ${ }^{*}{ }^{\text {wh }}$ or-juuren spontaanisti, affektin vaikutuksesta palatalisoitunut variantti (lähinnä ${ }^{*} g^{h} e r-$ ). Joka tapauksessa sen odotuksenmukainen katoaste on kantabaltin ${ }^{*} z$ ir -, josta jollakin $g$-johdoksella on saatu liettuan 'kipinää' merkitsevät žirgsnis ja žiežirga ('žiež-žirg-, vrt. Smoczyński SEJL s.v. žiežzirba). Latviassa hyvin lähelle niitä tulee $d z i r k s t e l e$-sanan synonyymi zirkste (lv. $z$, lt. $\check{z}<$ kba. ${ }^{*} z \dot{z}$ ). Myös mainittu lv. - $k$-johdin saattaa olla sama kuin lt. $-g$-, sillä sen asema myöhemmän -st-johtimen edellä neutraloi soinnillisuusopposition; toisaalta johtimen soinnillisuus liettuassa saattaa johtua affektista.

Kaiken kaikkiaan viimeistään kantaitäbaltissa on varmaankin ollut 'kipinän' merkityksessä rinnan katoasteiset ${ }^{*}$ gir-k/g- ja ${ }^{*} z i r-k / g$, joista kummassakaan ei ${ }^{*} g^{\text {wh }}$ orjuuri edustu ainakaan säännönmukaisesti. Edellisessä, lv. dzirkst-sanueen kantamuodossa ja ksm. ${ }^{*}$ kirki-sanan lähtömuodossa, on epäodotuksenmukainen $i$, jonka mahdollisesti selittää jälkimmäisen vaikutus. Jälkimmäinen, sanojen lt. žirgsnis ja žiežirga ja lv. zirkste kantamuoto taas palautuu joko aivan toiseen, sattumalta sekä äänteellisesti että semanttisesti tätä muistuttavaan juureen ${ }^{*} \dot{g}^{(h)} \operatorname{er}(H)$-, tai, mitä itse todennäköisempänä pidän, ${ }^{*} g^{w h} o r$-juuren ekspressiiviseen, vasta (esi)baltoslaavissa syntyneeseen varianttiin ${ }^{*} g^{h} e r$.

Itäbalttilaisissa kielissä on 'kipinän' merkityksessä muitakin äänteellisesti samankaltaisia sanoja: lv. birksts, birkstele; lt. pirkšnis, lv. pirksts; lt. žibirkštis; lt. kibirkstis, lv. cibirkste (ME, Kurschat LDW). Useimmat sanakirjojen (ME, s.v. pirksts; LEW, s.v. beržas, pirkšnis, žibe I; SEJL s.v. kibirkštis) näille esittämät etymologiat ovat semanttisesti enemmän tai vähemmän epäilyttäviä. Todennäköisesti ainakin enimmät muodot ovat syntyneet affektin ja erilaisten kontaminaatioitten kautta * girkst- ja ${ }^{*}$ žirkst-kantojen sekoittuessa eri verbivartaloihin: kba. ${ }^{*}$ bir $(\bar{e})$ - (> lt. birti, bireiti (byreti $)$, 
lv. birt, birēt 'streuen, ausfallen, verstreut, zerstückelt werden, zerbröckeln', LEW), kba. ${ }^{*}$ per- (> lt. perti '(ein)schlagen, stark donnern'), ${ }^{*} z \dot{i} b \bar{e}$ - (> lt. žibèti 'glänzen, glänzend strahlen, schimmern, leuchten, blitzen', LEW3) ja *kib- (> lt. kibti 'sich anhängen, anhaken, sich heranmachen, in etwas eindringen, angreifen', LEW). Sanojen lt. kibirksttis ja lv. cibirkste äänteellinen yhteys sm. kipinään on siis sattuman tulosta.

\section{Kahdesti kirkastettu?}

Kirki-sanueeseen Hakulinen liittää adjektiivin kirkas, joka ei ole kovin laajalle levinnyt, vaikka kuuluukin suomessa yleisimpiin adjektiiveihin. SSA merkitsee karjalan sanan kirkas uudeksi ja viron sanan kirgas lainaksi suomesta, mikä panee epäilemään, voisiko myös vatjan tširkas olla suomalaisperäinen. Sanan myöhäisyyteen viittaa myös äännerakenne: geminaatta pitkän tavuaineksen jäljessä ei ole palautettavissa kantasuomen viimeistä vaihetta pitemmälle. Sekundaarin geminoitumisen mahdollisuutta tukee Hakulisen esittämä johdossuhdeparalleeli kärki $\Rightarrow$ kärkäs.

Kipinä on ilmiselvästi kirkas, joten onko kirkas siis erotettava\#kiri-fonesteemin yhteydestä? Hakulisen selityksessä ongelmana on epäsäännöllinen johdossuhde, josta löytyy vain yksi rinnakkaistapaus ja sekin semanttisesti hämärä: SMS tuntee adjektiiville kärkäs vain merkitykset 'halukas, innokas, hanakka; herkästi jtak tekevä', kärkeen liittyvä terävyyden komponentti siltä puuttuu.

SSA:n kannattamalle yhteydelle kirkua-verbiin on osoitettavissa enemmän ja selvempiä paralleeleja. Forsberg esittää \#raji-fonesteemin yhteydessä aivan samaa johdossuhdetta adjektiivin raikas ja verbin raikua välille (Kulonen 2oro: I23). Niinpä kirkas voisi olla ääntä mukailevaa lähtöä samoin kuin Itkosen (1966: 372) esimerkkeinä synestesiasta mainitsemat adjektiivit heleä ja räikë̈. ${ }^{4}$ Samoin saksan hell'kirkas, valoisa; vaalea' on Klugen ja Seeboldin (2002) mukaan ensisijaisesti viitannut kimeään ja korkeaan ääneen ja synesteettisen metaforan kautta saanut nykyään tavallisemmat, valon tai värin määrän viittaavat merkityksensä. Päinvastaisessakin tapauksessa, substantiivin kirki johdoksena, on ainakin adjektiivin nykyinen käyttö ääntä kuvaavissa yhteyksissä - vrt. Kielitoimiston sanakirjan esimerkit kirkas pojanääni, kirkas sopraano ja builun kirkkaat sävelet - muokkautunut osaksi ääntä mukailevaa sanastoa, jossa ki-alkuisuus viittaa korkeisiin ääniin: kileä, kimeä, kilkata, kirkua, kirskua jne.

\footnotetext{
3. Tästä on johdettu myös lv. zibens 'salama', johon Viitso (1992: I7I) on liittänyt sm. kipinä-sanan esibalttilaisena lainana. Sanaa ei kuitenkaan ole välttämätöntä olettaa näin vanhaksi, etenkään kun merkitys ei täsmää.

Lätin sanan verbijohdos (Nötk) zibāt'sich schnell bewegen', (Bauske) zibelèt'sich schnell hin und her bewegen' (ME) on kuitenkin lainautunut viroon: sibama, sibelema 'davon laufen, hin und her laufen, sich schnell hin und her bewegen, nicht still halten' (EdW). Koska lätin verbin motivaatio on ilmeinen (vrt. sa. blitzen 'sich schnell bewegen'), ei viron verbejä ole syytä EES:n (s.v. sibama) tavoin pitääänteellisesti motivoituina, vaan lainana latviasta.

4. Näistä rinnastuksista kiitän artikkelini vertaisarvioijaa.
} 


\section{Säteitä meren takaa?}

Hakulinen selittää kirjen vanhana äänteellisenä muuntumana viron ja eteläviron sanat kiir (: kiire)'säde' ja kiirgama'säteillä', vrt. vs. Nóo kiirg 'liekki'. Tätä etymologiaa tukee edelleen mm. EES. Vokaalin piteneminen selittyisi synesteettisellä äännesymboliikalla hyvin - säteethän ovat pitkänomaisia - jos vain kiir olisi tulkittavissa motivaatioltaan ekspressiiviseksi. Tällöin myös klusiilin kadon saattaisi selittää sen assosioituminen tilkeainekseksi. Kun kyseessä kuitenkin on konkreettistarkoitteinen substantiivi, on muitakin alkuperäselityksiä hyvä hakea. Nostan tässä kolme lainaetymologiaa harkittaviksi.

Ensinnäkin voidaan lähteä keskialasaksin sanasta schîr n. 'eine offene Bahn durch das Reith (am Ufer des Zwischenahner Meeres), so dass man mit dem Kahne hindurchfahren kann zum oder vom Lande. Dergleichen Durchfahrten durch das Reith finden sich viele am Ufer dieses Meeres', joka MndW:n mukaan on johdos verbistä scheren 'jakaa, leikata'. Tällöin merkityksen 'säde' taustalla olisi 'oikotie, leikkaus, suorin matka kahden pisteen välillä' ja merkitys 'valonsäde' olisi kehittynyt vasta sekundaarista yhteydestä vanhempaan sanaan kirg 'kipinä, liekki'. Tällainen etymologia on kuitenkin hyvin epätodennäköinen: yhtäältä kiir-sanan $e$-vartaloisuus viittaa keskialasaksia varhaisempaan lainanlähteeseen ja toisaalta luultavin motivaatio sädettä merkitsevälle sanalle on 'valonsäde'.

Toiseksi 'säde' tulee lähelle ruotsin skir n. sanan harvinaisehkoa merkitystä 'glans, sken, skimmer; i sht i fråga om ljus från en himlakropp (särsk. grynings- 1 . aftonljus)', joka SAOB:n mukaan on adjektiivin skir (< msk. skirr $\rightarrow$ sm. kiira) 'kirkas, puhdas, selkeä' substantivoituma 'kirkkaus' > 'loiste, kajo' eikä siis ensisijaisesti liity yleisempään substantiiviin skir'harso'. SAOB tuo esimerkkeinä kirjallisuudesta lauseet Om de döda stiga opp / I månens skir (c. I870) ja Månens strålar föllo öfver bennes panna och inväfde hela gestalten $i$ ett skir af öfverjordiskt ljus (1889). Sanan lainautuminen viroa edeltäneisiin itämerensuomalaisiin murteisiin edellyttäisi siis merkityksenkehitystä 'kirkkaus' / 'taivaankappaleen loiste' > 'säde' joko lähtö- tai kohdekielessä. Lähtökielenä on pidettävä kantaskandinaavia tai viimeistään muinaisruotsia.

Kolmas mahdollinen lähtömuoto on rekonstruoitavissa islannin sanojen gisli m. 'säde' ja gill m. (= no. murt. gil) 'kirkas piste pilvipeitteessä, sädekehä, halo' pohjalta. Edellinen palautuu Kroonenin (EDPG s.v. * gissla-) mukaan kantagermaanin muotoon ${ }^{*}$ gislaz ja jälkimmäinen alun perin päätepainolliseen muotoon ${ }^{*} g \bar{i} z l a z$. Molemmat on muodostettu kantaindoeurooppalaisella - $l$-johtimella $e$-asteisesta vartalosta ${ }^{*} g^{h}$ eis-, jonka $o$-asteinen johdos on kge. * gaizaz 'keihäs; huippu, kärki'; tästä on lainautunut sm. keibäs ja sanan myöhemmästä skandinaavisen $z>r$-kehityksen jälkeisestä muodosta sm. kaira. Lainaetymologia edellyttäisi joko konsonanttiyhtymän -rl-yksinkertaistumista lainautuessa ksk $\left({ }^{*} \text { gizzla- }>\right)^{*}$ gìrla- $\rightarrow \mathrm{ksm} .{ }^{*} k$ iiri tai lähtökielen $e$-asteista $\left({ }^{*} g \bar{\imath} z->\right)^{*} g \bar{\imath}$-kantaista muotoa ilman -l-johdinta. Koska oletetulla lähtömuodolla ei ole tarkkoja vastineita, on etymologia epävarma.

Jokainen kolmesta lainaetymologiasta selittäisi kiir-sanan äänneasun paremmin kuin johdosselitys $\Longleftarrow k i r g$ antamalla mahdollisuuden luopua vokaalin pitenemisen 
ja sanansisäisen klusiilin kadon oletuksesta. Verbin kiirgama -g-olisi helposti selitettävissä sekundaariksi vaikutukseksi merkitykseltänsä läheisestä kirg-sanasta. Esitetyistä etymologioista todennäköisimpänä pidän lainautumista ruotsin skir-sanaa edeltävästä muodosta.

Myös kiiriä liittyy'säteen' merkityskenttään ja etenkin ruotsin skir-sanan 'loisteeseen': kissan silimä kiirii 'kiiluu' (Ilomantsi, SMS). Verbi saattaa siis selittyä johdoksena sanasta *kïri 'säde', vaikkei sillä olekaan vastineita suomen ulkopuolella. Forsberg (Kulonen 2oro: 154) pitää suppealevikkisen kiiriä-verbin yhteyttä \#kiji-fonesteemiin ( kiikku, kiikkerä, kiikki) epävarmana. Epäily on oikeutettua, sillä -r- ei kuulu usein käytettyihin tilkekonsonantteihin (s. 239) ja semanttisestikin kiiriä tulee lähemmäs tässä käsiteltyä \#kiri-fonesteemia.

\section{Kiire on nuorta kauppatavaraa}

Lopuksi Hakulinen yhdistää kirki-pesyeeseen myös kiireen olettamalla samoja sporadisia äänteenmuutoksia kuin kiir-sanaan. Merkitysparalleeleiksi Hakulinen tarjoaa suomesta sanaa bäkärä, jolle Lönnrot antaa merkityksiksi yhtäältä 'kåthet, kättja, brunst, trånad' (SMS 'tarve, halu, into, kiihko, himo'), toisaalta 'hast, ifver' (SMS 'kiire; pula, hätä), muista kielistä ruotsin sanaa bråd 'kiireellinen; kuuma' ja ranskan sanaa tôt 'pian'< lat. tostum 'poltettu'.

Kiire on kuitenkin hyvin laajalevikkinen pohjoisessa ja keskisessä itämerensuomessa, vaikka puuttuukin eteläisimmästä kielistä liivistä ja etelävirosta. Sen kohdalla vokaalin piteneminen ja klusiilin kato olisi siis selitettävä hyvin varhaiseksi, jo ainakin kantasuomen Suomenlahden murteen äännekehitykseksi. Sanalla on kolme kaksitavuista päätevarianttia, -eh-, - ub- ja - u-, ekspressiiviselle sanalle siis varsin maltillinen määrä, etenkin kun eri variantit ovat murrealueittain lähes täydennysjakaumassa, ilman suuria päällekkäisyyksiä: smI kiire, ka. kiireh, va. tšiire, vi. kiire smL kiiru, vi. kiir: $-u \sim$ ve. kiruh.

Kiire on suomessa ensisijaisesti substantiivi 'hoppu, hätä' ja toissijaisesti adjektiivi 'kiireinen, kiireellinen', vrt. no èi tässä niïn kiirettä òj jottei läbttee? ?ennätä (SMS: Nilsiä); mull_on kiirehet työt siellä mökilläni (SMS: Himanka). Sama pätee karjalaaan (kiireh) ja vepsään (kiruh). Viron kirjakielessä kiire on yleisimmin adjektiivi 'nopea' ('nobe, kärmas'), harvemmin substantiivi suomen tapaan ('rutt'): Jögi on üsna kiire vooluga; Mul pole kuskile suurt kiiret (EKSS). Viron murteiden sanakirjassa sanan substantiivisesta käytöstä on kuitenkin esimerkkejä hyvin laajalta alueelta, ja adjektiivinakin sen merkitys on useammin substantiivin merkityksestä johdettu 'kiireinen, kiireellinen' kuin ensisijaiseen adjektiivisuuteen viittaava 'nopea'. Ilmeisesti kiire siis palautuu koko levikkialueellaan vanhaan substantiiviin ja sen adjektiivinen käyttö on uudempaa.

Saksassa on adverbi schier 'melkein, lähes' ('beinahe, fast'), joka ei etymologisesti liity adjektiiviin schier 'puhdas, aito' (tämä kuuluu yhteen yllä mainitun ruotsin sanan skir 'kirkas, puhdas, selkeä' kanssa). Nykysaksassa ensin mainittua schier-sanaa 
ei käytetä adjektiivisesti, mutta vielä keskiyläsaksassa sillä oli merkitys 'pian tuleva t. koittava', yleensä superlatiivisesti käytettynä 'seuraava' auf den schiersten montag 'seuraavana maanantaina' (Grimm DWB). Adverbina keskiyläsaksan schier(e) merkitsi sekä 'nopeasti, pian' että 'melkein'. Jälkimmäinen merkitys on jo Grimmin mukaan uudempi. Samansuuntaisen merkityksenkehityksen 'pian' > 'melkein' on käynyt läpi myös saksan fast. Virossakin pea merkitsee sekä 'pian' että 'melkein, lähes'.

Muinaisyläsaksassa adverbi oli muodossa skiaro 'nopeasti, heti', mutta sitä vastaava adjektiivi skêri esiintyy teksteissä merkityksessä 'scharf, hitzig im Aufspüren, scharfsichtig im Erforschen', siis 'terävä, nopeaälyinen' eli joku jolla "leikkaa”. Sana onkin luultavasti johdettu ie. juuresta ${ }^{*}$ skerH- 'leikata', josta myös $>$ sa. scheren 'leikata', aiemmin myös 'kiirehtiä'. Keskialasaksissa scheren merkitsi myös 'mennä, juosta, kiiruhtaa', jossa taustalla lienee 'leikata' > 'oikaista', vrt. sa. aus dem Kurs scheren 'poiketa kulkusuunnasta' > 'kiiruhtaa': tähän liittyy myös ylempänä mainittu schîr 'eine offene Bahn durch das Reith'.' Keskialasaksissa adverbi schere, schî, schire ja keskihollannissa $s c(h)$ ier merkitsivät 'pian, nopeasti, heti; suunnilleen, melkein' (Kluge \& Seebold 2002, MndW).

Muinaisskandinaavissa ei ole vastinetta schier-adjektiiville eikä adverbille, ja länsigermaanin sanat viittaavat kantagermaanin muotoon ${ }^{*} s k e \bar{r}$ - $\left(\mathrm{EWgP}{ }^{*} s k \bar{e}_{2} r-\right)$, joka vokaalinsa puolesta ei sovi lainanlähteeksi. Niinpä kiire kiiru onkin voitu saada vasta keskialasaksista, jossa $\bar{i}:$ llinen muoto esiintyy yleisesti $\bar{e}: 1$ lisen rinnalla. MndW mainitsee sen käytöstä esimerkit schirst kumftich 'nächst kommende', mit dem schiersten 'baldmöglichst' ja dat he betalen wil schir efte morgen (s.v. schere) sekä do nu de meister schir wedder wech wolde, sprack he (s.v. schire). Substituutio kas. sch- [sk-] $\rightarrow$ ims $k$ - on odotuksenmukainen, vrt. kas. schip $\rightarrow$ sm. kippa (Bentlin 2008: 68), kas. schicht $(e) \rightarrow$ vi. kibt, kas. schenke $\rightarrow$ vi. kink jne. (ASL).

Schir(e)! 'nopeasti!' tai ehkä schîr(e)-schîr(e)! 'hop hop!' saattoi olla komento, jota hansakauppiaita satamissa ja laivoissa palvelleet itämerensuomalaiset joutuivat työnjohtajiltaan kuulemaan. Tällaiset ilmaisuthan opitaan helposti muuten aivan vieraastakin kielestä. Varhaisen kapitalismin airuena yksitavuinen interjektio *kiir! levisi näin itämerensuomalaisten puheessa laajemmalle kuin myöhemmät alasaksilaislainat, idässä aina vepsään saakka. Substantiivi *kiireh *kiiruh *kiiru on tällöin johdos interjektiosta *kiir! samaan tapaan kuin hoppu saattaa olla johdos interjektiosta hop! (NES), mutta laajemman levikin myötä mukana on enemmän vartalovaihtelua. Muita mahdollisia vepsään ulottuvia alasaksilaislainoja ovat Bentlinin (2008: 78, 86, 274) mukaan märssy, nuotio ja rikki.

Varmaa kiireen interjektioperäisyys ei ole, kuten ei hopunkaan, jolla on karjalassa myös merkitykset 'tuska, vaiva' ja 'riita, suukopu' (KKS). Toisaalta kiire on ilmeinen Suomenlahden alueen sana, jolta puuttuvat vastineet niin liivistä kuin etelävirostakin, kahdesta jo rautakaudella muista erilleen kasvaneesta kantasuomen haarasta. Se onkin

5. Näin MndW s.v. schîr. Toisin Knapp (1974: 209), joka pitää kantana ie. verbiä * skēi- 'erottaa' (näin myös EWgP s.v. $s k \bar{e}_{2} r i$ ja Kluge \& Seebold 2002 s.v. schier), mutta tämä ei kuitenkaan sovi merkitykseen 'nopeasti, pian'. 
mahdollista selittää myös kantagermaanisena lainana. $\mathrm{EWgP} \mathrm{(s.v.} \mathrm{skē} \mathrm{ri} r$ ) esittää tässä mainitun germaanisen sanueen kanssa löyhemmin yhteen kuuluvina kaksi kge. ${ }^{*}$ skeirkannasta johdettua sanaa, muinaisyläsaksan (Abrogans-sanaluettelosta noin vuodelta 750 tavattu) substantiivin skìra 'Geschäft, Aufgabe, Obliegenheit' ja muinaisenglannin verbin sciran 'in Ordnung bringen'. Muinaisyläsaksan muodon aiempi, kantagermaaninen asu ${ }^{*}$ skeirō sopisi jo sellaisenaan substantiivin kiiru (josta kiire olisi tällöin myöhempi johdos) lähtömuodoksi, ovathan kiireet yleensä 'hoidettavia asioita'.

\section{Fonesteemin vetovoima}

Fonesteemin \#kiri- konventionaalinen äännesymboliikka näyttää muodostuneen kerros kerrokselta, kun imitatiivisen ja synesteettisen aineksen päälle on kasautunut monenlähtöisiä sanoja, joitten merkityksenkehitystä on ohjannut aiempien kerrostumien semantiikka, toisin sanoen fonesteemi itse.

Lähtökohtina ovat olleet yhtäältä ääntä mukaileva ${ }^{*}$ kire- *kir-k-u- (> vi. kireda 'kiekua' ja sm. kirkua kirkkua kirskua), toisaalta synesteettisesti äännekonventionaalinen ${ }^{*}$ kire- $\Rightarrow{ }^{*}$ kiretä $\left(>\mathrm{sm}\right.$. kireä) ja ${ }^{*}$ kireš $(>\mathrm{sm}$. kire). Vasta pohjoisessa itämerensuomessa on adjektiivi kirkas syntynyt kirkua-verbin johdoskorrelaatiksi ja tuonut synesteettisen äännekonvention 'kirkas ääni' 'kirkas valo' kautta fonesteemille merkityskomponentiksi myös 'valoisuuden'. Tämän merkityksenlaajentuman on taustalla on voinut vaikuttaa balttilaisperäinen kirki, jos se on täälläkin merkinnyt 'kipinää' vielä tuolloin: sitä voisi siis pitää \#kiri-fonesteemin sukulaisena "väärän koivun takaa".

Jos viron kiir 'säde' (< *kiiri) on saatu skandinaavisista kielistä, sen lainautumista on varmasti motivoinut äänteellis-semanttinen yhteys 'kipinää' merkinneeseen kirki-sanaan. Pohjoisesta itämerensuomesta ${ }^{*}$ kiiri on sittemmin kadonnut, mihin on varmaankin myötävaikuttanut se, ettei kirjen alkumerkityskään ole täällä säilynyt. Johdos kiiriä osoittaa sanan kuitenkin kuuluneen myös Suomenlahden pohjoispuoleisten muinaismurteitten sanastoon. Täällä puolestaan skandinaavisperäinen on suomen kiira 'puhdas, kirkas', ja sen omaksumiseen on tarjonnut tarttumapintaa 'valoisuuden' komponenttinsa suhteen lähes synonyyminen kirkas.

Kumpikin skandinaavista saatu lisä on tahollaan kasvattanut \#kiri-fonesteemin "valoisaa" komponenttia. Suomen murteissa myöhemmät ruotsalaislainat kiiri' (paha) mieliala' ja kiiras 'peräänantamaton, tiukka; kitsas, nuuka' taas ovat kireän (ja kireen) kieleen vetäminä voimistaneet fonesteemin vanhempaa, "tiukkaa" ja "ankaraa" suuntaa, joka on kiirastulessa saanut uskonnollisenkin ulottuvuuden. Etelämpänä fonesteemi on virittynyt aivan päinvastaisiin 'himokkuuden' merkityksiin, kun eteläviron saksalaisperäinen kiiras'raisu; kiimainen' voimistaa vanhempaa kirki-sanuetta.

Mahdollisen alasaksilaislähtöisen interjektion kiir! ja siitä ehkä johdetun kiiresubstantiivin juurtumiseen on hyvinkin voinut myötävaikuttaa yhteys kireä̈n, kiristäähän kiire tunnetusti pinnaa. Kiireen kyydissä on puolestaan saanut alkunsa \#kiripesyeen uusin substantiivi, sanojen kireä ja kiristää yleiskielinen johdoskorrelaatti kiri. 


\section{Lyhenteet}

$\begin{array}{llll}\text { ie. } & \text { kantaindoeurooppa } & \text { murt. } & \text { murteissa } \\ \text { ka. } & \text { karjala } & \text { n. } & \text { neutri(sukuinen) } \\ \text { kas. } & \text { keskialasaksi } & \text { no. } & \text { norja } \\ \text { kba. } & \text { kantabaltti } & \text { ru. } & \text { ruotsi } \\ \text { kge. } & \text { kantagermaani } & \text { sa. } & \text { saksa } \\ \text { ksl. } & \text { kantaslaavi } & \text { saaP } & \text { pohjoissaame } \\ \text { kysa. } & \text { keskiyläsaksa } & \text { sm. } & \text { suomi } \\ \text { lat. } & \text { latina } & \text { smI } & \text { suomen itämurteet } \\ \text { lt. } & \text { liettua } & \text { smL } & \text { suomen länsimurteet } \\ \text { lv. } & \text { latvia } & \text { va. } & \text { vatja } \\ \text { m. } & \text { maskuliini(sukuinen) } & \text { ve. } & \text { vepsä } \\ \text { mas. } & \text { muinais(ala)saksi } & \text { ven. } & \text { venäjä } \\ \text { mksl. } & \text { muinaiskirkkoslaavi } & \text { vi. } & \text { viro } \\ \text { msk. } & \text { muinaisskandinaavi } & \text { vs. } & \text { eteläviro (vóro-setto) }\end{array}$

\section{Sanakirjalähteet}

ASL = VIIKBERG, JÜRI 2OII-I3: Alamsaksa laensõnad eesti keeles. $\langle$ http://www.eki.ee/dict/asl/>.

DWB = Grimm, JACOB \& GRIMm, Wilhelm I854-1960: Deutsches Wörterbuch I-XVI. Leipzig.

EDBIL = DERKSEN, RICK 2OI5: Etymological dictionary of the Baltic inherited lexicon . Leiden Indo-European etymological dictionary series I3. Leiden - Boston: Brill.

EDW = WIEDEMANn, FERDINANDJohann I869: Ebstnisch-deutsches Wörterbuch. St. Petersburg. EDPG = Kroonen, GuUs 2013: Etymological dictionary of Proto-Germanic. Leiden IndoEuropean etymological dictionary series I3. Brill.

EES $=$ Iris Metsmägi \& Meeli Sedrik \& Sven-Erik Soosaar (toim.) 2oi2: Eesti etümoloogiasõnaraamat. Tallinn: Eesti Keele Sihtasutus.

EMS $1994-(2016)=$ Eesti murrete sónaraamat $\mathrm{I}-(27)$. Tallinn: Eesti Keele Instituut.

EKSS 2009 = Eesti keele seletav sõnaraamat. „Eesti kirjakeele seletussónaraamatu” 2., täiendatud ja parandatud trükk. Tallinn: Eesti Keele Sihtasutus.

EWGP = HEIDERMANns, FRANK 1993: Etymologisches Wörterbuch der germanischen Primäradjektive. Studia Linguistica Germanica 33. Berlin - New York: Walter De Gruyter.

HGE = OreL, VLADIMIR 2003: A handbook of Germanic etymology. Leiden - Boston: Brill.

Kielitoimiston sanakirja. 20I8. Helsinki: Kotimaisten kielten keskus. $\langle$ https://www.kielitoimistonsanakirja.fi/>. Päivitetty 6.6.20I8.

KKS ${ }_{1968-2005}$ = Karjalan kielen sanakirja I-VI. Helsinki: Suomalais-Ugrilainen Seura.

Kluge, Friedrich \& Mitzka, Walther 1967: Etymologisches Wörterbuch der deutschen Sprache. 20., bearbeitete Auflage. Berlin: Walter De Gruyter.

Kluge, Friedrich \& Seebold, Elmar 2002: Etymologisches Wörterbuch der deutschen Sprache. 24., durchgesehene und erweiterte Auflage. Berlin: Walter De Gruyter.

LDW = Kurschat, AleXANder 1968-73: Litauisch-deutsches Wörterbuch. Göttingen: Vandenhoeck \& Ruprecht.

LEV = KARULIs, KonstANTĪNs 1992: Latviešu etimoloğijas vārdnīca divos sējumos. Rīga: Avots. 
LEW = FRAENKEL, ERNST 1955-65: Litauisches etymologisches Wörterbuch I-2. Göttingen: Vandenhoeck \& Ruprecht.

LägloS = Andries Dirk Kylstra, Sirkka-Liisa Hahmo, Tette Hofstra \& Osmo NikкILÄ 199I-2012: Lexikon der älteren germanischen Lebnwörter in den ostseefinnischen Sprachen I-3. Amsterdam - Atlanta: Rodopi.

Lönnrot, Elias 1874-80: Suomalais-Ruotsalainen Sanakirja. Helsingissä: Suomalaisen Kirjallisuuden Seura.

ME = JĀNIs ENDZELĪNS (TOIM.) I923-32: K. Mülenbacha Latviešu valodas vārdnīca I-IV. Rīga: Kultūras fonds.

MndW = Schiller, Karl \& LübBen, August i875-81: Mittelniederdeutsches Wörterbuch I -VI. Bremen: Kühtmann.

NES = HÄKKINEN, KAISA 2004: Nykysuomen etymologinen sanakirja Juva: WSOY.

SAOB I893-(2017) = Svenska Akademiens ordbok $\mathrm{I}-(37)$. Lund.

SEJL = SMOCZYŃsKi, WojCIECH 2007: Stownik etymologiczny języka litewskiego. Wilno: Uniwersytet Wileński, Wydział Filologiczny.

SKES I955-8I = Suomen kielen etymologinen sanakirja I-VII. Helsinki: Suomalais-Ugrilainen Seura.

SMS 1985-(2008) = Suomen murteiden sanakirja $\mathrm{I}-(8)$. Helsinki: Kotimaisten kielten tutkimuskeskus.

SSA $1992-2000=$ Suomen sanojen alkuperä. Etymologinen sanakirja $\mathrm{I}-3$. Helsinki: Kotimaisten kielten tutkimuskeskus - Suomalaisen Kirjallisuuden Seura.

\section{Muut lähteet}

Bentlin, Miкко 2008: Niederdeutsch-finnische Sprachkontakte. Der lexikalische Einfluß des Niederdeutschen auf die finnische Sprache während des Mittelalters und der frühen Neuzeit. Suomalais-Ugrilaisen Seuran Toimituksia 256. Helsinki: Suomalais-Ugrilainen Seura.

Hakulinen, Lauri 1933: Suomen kirki ja kiire - Virittäjä 37: 159-166.

Itroonen, ErkKi 1966: Kieli ja sen tutkimus. Universitas 4. Helsinki: Werner Söderström Osakeyhtiö.

JARVA, VESA 2003: Venäläisperäisyys ja ekspressiivisyys suomen murteiden sanastossa. Jyväskylä: Jyväskylän yliopisto, suomen kielen laitos.

Junttila, SANTERI 20I5: Tiedon kumuloituminen ja trendit lainasanatutkimuksessa. Kantasuomen balttilaislainojen tutkimushistoria. Helsinki: Helsingin yliopisto.

Knapp, Fritz Peter 1974: Wiederum germanisches $e^{2}$. - Beiträge zur Geschichte der deutschen Sprache 96: 207-240.

Koivulehto, Jorma 1974: Lisiä germaanis-suomalaisiin lainakosketuksiin. - Virittäjä 78 : III-I27.

Kulonen, Ulla-Maija 20io: Fonesteemit ja sananmuodostus. Suomen kontinuatiivisten u-verbijobdosten historiaa. Helsinki: Suomalaisen Kirjallisuuden Seura.

Matasović, Ranko 2008: Poredbenopovijesna gramatika brvatskoga jezika. Zagreb: Matica hrvatska.

Sperber, Hans 1923: Einführung in die Bedeutungslehre. Bonn - Leipzig: Kurt Schroeder Verlag.

STRENG, HARRY Johannes I9I5: Nuoremmat ruotsalaiset lainasanat vanhemmassa suomen kirjakielessä. Helsinki: Suomalaisen Kirjallisuuden Seura.

Virtso, Tirt-Rein 1992: Proto-Indo-European laryngeals in Uralic. - Linguistica Uralica XXVIII: I6I-I72. 